\title{
Biological and economic efficacy of cowpea-radish association fertilized with organic manure in diverse planting arrangements
}

\author{
Eficácia biológica e econômica da associação de caupi e rabanete fertilizada com adubo orgânico \\ em diversos arranjos de plantio \\ Eficacia biológica y económica de la asociación de caupí y rábano fertilizados con abono orgánico \\ en diversos arreglos de plantación
}

Received: 08/10/2021 | Reviewed: 08/18/2021 | Accept: 08/24/2021 | Published: 08/25/2021

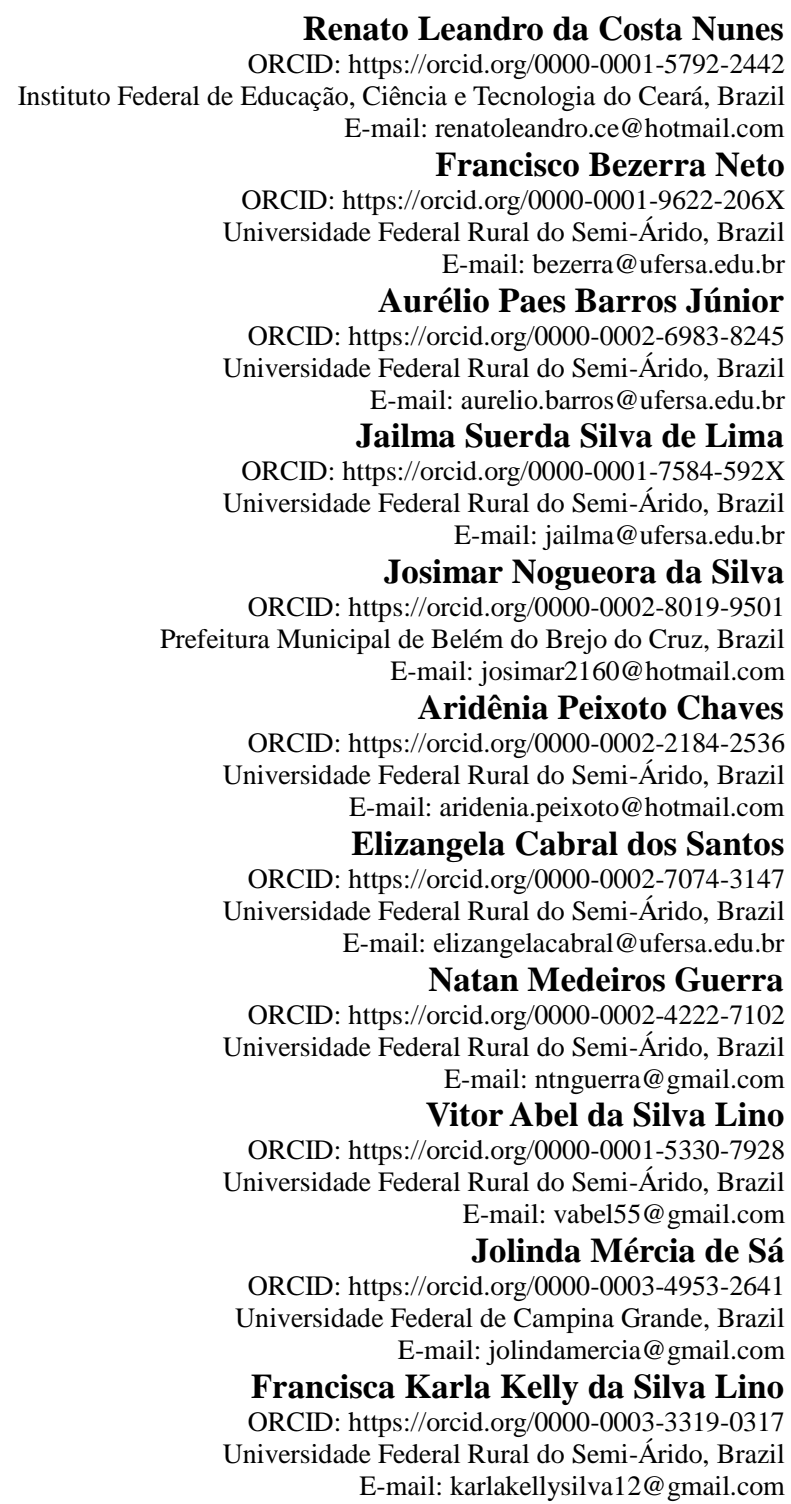

\begin{abstract}
Green manuring and the spatial arrangement of planting intercropped crops are manageable factors to increase the bioeconomic effectiveness of intercropped systems. Therefore, the object of this study was to work out the bioeconomic efficacy in cowpea-radish association under diverse Calotropis procera biomass amounts and planting arrangements in two cultivation seasons through biological and economic indices. The research was conducted in a design of randomized complete blocks with four repetitions. The treatments were made of combination of four $C$. procera biomass amounts placed into the soil $\left(20,35,50\right.$ and $\left.65 \mathrm{t} \mathrm{ha}^{-1}\right)$ with three cowpea-radish planting
\end{abstract}


arrangements (2:2, 3:3 and 4:4). The biological indices, land equivalent ratio (LER), area-time equivalency ratio (ATER), actual yield loss (AYL), and system productivity index (SPI) and the economic indicators gross revenue $(\mathrm{GR})$, net revenue (NR), rate of return (RR) and profit margin (PM) were evaluated to express the bio-economic efficacy of the cowpea-radish association. The greatest biological efficiencies of the cowpea-radish association were attained with LER and ATER of 1.75 and 1.25; AYL and SPI of 1.48 and $13.15 \mathrm{t} \mathrm{ha}^{-1}$, respectively, in the amount of $62 \mathrm{t} \mathrm{ha}^{-1}$ of $C$. procera biomass in the planting arrangements 2: 2 and 3: 3. The largest net economic revenue (NR) of $16,382.85 \mathrm{R} \$ \mathrm{ha}^{-1}$ was attained in the amount of $52 \mathrm{t} \mathrm{ha}^{-1}$ of $C$. procera in the planting arrangement 3: 3.

Keywords: Vigna unguiculata; Raphanus sativus; Calotropis procera; Biological índices; Economic indicators.

\section{Resumo}

A adubação verde e arranjo spatial de plantio das culturas em consórcio são fatores manipuláveis para aumentar a eficácia bioeconômica dos sistemas consorciados. Portanto, o objeto desta pesquisa foi avaliar a eficácia bioeconômica do consórcio de caupi e rabanete sob diversas quantidades de Calotropis procera e arranjos de plantio em duas safras de cultivos por meio de índices biológicos e indicadores econômicos. A pesquisa foi conduzida em blocos completos casualizados com quatro repetições. Os tratamentos foram compostos pela combinação de quatro quantidades de $C$. procera adicionadas ao solo $\left(20,35,50\right.$ e $\left.65 \mathrm{t} \mathrm{ha}^{-1}\right)$ com três arranjos de plantio de caupi e rabanete (2: 2, 3: 3 e 4: 4). Os índices biológicos, razão equivalente de terra (RET), razão de equivalência de área-tempo (REAT), perda de rendimento real (PRR) e índice de produtividade do sistema (IPS), e os indicadores econômicos de receita bruta $(\mathrm{RB})$, receita líquida (RL), taxa de retorno (TR) e índice de lucratividade (IL) foram avaliados para expressar a eficácia bioeconômica da associação caupi e rabanete. As maiores eficiências biológicas do consórcio caupi e rabanete foram obtidas com RET e REAT de 1,75 e 1,25; PRR e IPS de 1,48 e 13,15 $\mathrm{t} \mathrm{ha}^{-1}$, respectivamente, na quantidade de $62 \mathrm{t} \mathrm{ha}^{-1}$ de $C$. procera nos arranjos de plantio 2: 2 e 3: 3 . O maior retorno econômico líquido (NI) de 16.382,85 R \$ ha-1 foi obtido na quantidade de $52 \mathrm{t} \mathrm{ha}^{-1}$ de $C$. procera no arranjo de plantio 3: 3.

Palavras-chave: Vigna unguiculata; Raphanus sativus; Calotropis procera; Índices biológicos; Indicadores econômicos.

\section{Resumen}

La fertilización verde y la disposición espacial de la siembra de cultivos intercalados son factores manejables para aumentar la eficacia bioeconómica de los sistemas intercalados. Por lo tanto, el objeto de esta investigación fue evaluar la efectividad bioeconómica del cultivo intercalado de caupí y rábano bajo diferentes cantidades de biomasa de Calotropis procera y arreglos de siembra en dos temporadas de cultivo utilizando índices biológicos e indicadores económicos. La investigación se realizó en un diseño de bloques al azar con cuatro repeticiones. Los tratamientos

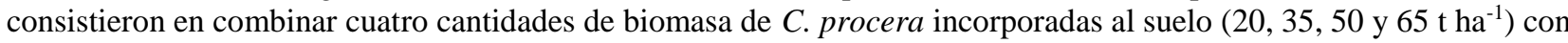
tres arreglos de siembra de caupí y rábano (2: 2, 3: 3 y 4: 4). Los índices biológicos, razón equivalente de tierra (RET), razón de equivalencia área-tiempo (REAT), pérdida de rendimiento real (PRR) e índice de productividad del sistema (IPS), e los indicadores económicos de ingresos brutos (IB), ingreso neto (IN), tasa de retorno (TR) y el índice de rentabilidad (IR) fueron evaluados para expresar la efectividad bioeconómica de la asociación entre caupí y rábano. Las mayores eficiencias biológicas de los cultivos intercalados de caupí y rábano se obtuvieron con RET y REAT de 1,75 y 1,25; PRR e IPS de 1,48 y 13,15 $\mathrm{t} \mathrm{ha}^{-1}$, respectivamente, en la cantidad de biomasa de $62 \mathrm{t} \mathrm{ha}^{-1}$ de $C$. procera en arreglos de plantación 2: 2 y 3: 3 . El mayor retorno económico neto (IN) de 16.382,85 Se obtuvo R $\$$ ha $^{-1}$ en la cantidad de $52 \mathrm{t} \mathrm{ha}^{-1}$ de $C$. procera en el arreglo de siembra 3: 3.

Palabras clave: Vigna unguiculata; Raphanus sativus; Calotropis procera; Índices biológicos; Indicadores económicos.

\section{Introduction}

Association of cowpea [Vigna unguiculata L. (Walp.)] with radish (Raphanus sativus L.) is beginning to be practiced in the northeast of Brazil (Pereira et al., 2016). These two crops are considered two companion crops of economic and nutritional value that can complement each other in an intercrop (Chaves et al., 2020). When associated they can increase the total yield per unit of land and of time, increase the diversity of products, reduce the economic risks of the producer and help to use the land, labor and other environmental recourses of the rural land efficiently and judiciously (Nunes et al., 2018).

The intercrop with these two crops has not been investigated in regard to the management factors green fertilizing and planting arrangements of cultures. The green manuring practice can provide a lot of benefits for improving the bio-economic efficacy of intercrops. It increases the organic matter quantity and provides higher nutrients availability; provides higher effective cation exchange capacity of soil; decreases the Al contents exchangeable for its complexation; and increases the 
capacity of recycling and mobilization of leached or poorly soluble nutrients that are in the deepest layers of the profile (Valadares et al., 2016).

Planting arrangement as a management factor in intercrops can be manipulated to enhance the usage of ambient recources and efficiency of these associations, thus defining the pattern of plants distribution in the soil, determining the area shape available for each plant individually. Thus, it constitutes an important production factor in the competition between crops, consequently, in the bio-agronomic efficacy of the intercrops (Chaves et al., 2020). Intra and interspecific competition in the intercrop is established by the plants disposition and by the spacing between and within planting lines. When the competition starts, the plants distribution pattern regarding the soil is defined and the area available for each individual plant in the usage of ambient recources is determined.

Therefore, to maximize the crops yield in intercrop, competition between and/or within the intercropped crops must be reduced, organizing them so that they can better use ambient recourses, and thus increase production and improve product quality (Schons et al., 2009). Researching the planting arrangements effect on cowpea-carrot intercrops in northeastern Brazil, Favacho et al. (2017), observed that planting arrangement 2: 2 provided greater producing and economic efficacy of intercrops. Conversely, researching the planting arrangements effect (2:2,3:3 and 4:4) in the beet intercrop with two successive lettuce crops in a semiarid environment, Silva et al. (2018) did not observe effect of these planting arrangements on production and economic efficacy of the intercrops.

Thus, the object of this study was to work out the cowpea-radish intercrop bio-economic efficacy under different $C$. procera biomass amounts in diverse planting arrangements in two cultivation seasons.

\section{Methodology}

In the field experiments, it followed the Bhatt (2011) recommendation for the statistical design, and for cowpea and radish crops management in intercropping and in monocropping, besides the materials used in conducting these experiments, they were used the methodologies established by Nunes et al. (2018); Pereira et al. (2018); Ribeiro et al. (2018) and Moraes et al. (2019).

\subsection{Locales, weather and soils}

The present work was accomplished in two sites of Rafael Fernandes farm at Universidade Federal Rural do SemiÁrido (UFERSA), Mossoró, Brazil (5॰11'S, 37॰20'W, 18 m altitude) from August to October of 2015 and 2017. The climate of the sites is BShw, semiarid, according to Köppen-Geiger's classification, dry and very hot, with two seasons: a dry (JuneJanuary), other rainy (February-May) (Alvares et al., 2014), reaching maximum average temperature between 32.1 and 34.5 ${ }^{\circ} \mathrm{C}$, minimum average between 21.3 and $23.7^{\circ} \mathrm{C}$, with June and July months being the coldest and the average annual rainfall around $685.3 \mathrm{~mm}$.

The soils of these sites were a typical Dystrophic Red Argisol (Santos et al., 2018), whose chemical analysis results are exposed in Table 1. 
Table 1. Soils chemical analyses before application of the Calotropis procera biomass.

\begin{tabular}{|c|c|c|c|c|c|c|c|c|c|c|c|c|c|}
\hline \multicolumn{14}{|c|}{ Content before incorporation of the Calotropis procera ${ }^{\dagger}$} \\
\hline \multirow{2}{*}{$\begin{array}{l}\text { Soils of } \\
\text { cropping sites }\end{array}$} & \multirow{2}{*}{$\begin{array}{c}\mathrm{N} \\
\mathrm{g} \mathrm{kg}^{-1}\end{array}$} & \multirow{2}{*}{$\begin{array}{c}\mathrm{pH} \\
\text { (water) }\end{array}$} & \multirow{2}{*}{$\begin{array}{c}\text { EC } \\
\mathrm{ds} \mathrm{m}^{-1}\end{array}$} & \multirow{2}{*}{$\begin{array}{c}\mathrm{OM} \\
\mathrm{g} \mathrm{kg}^{-1}\end{array}$} & $\mathrm{P}$ & $\mathrm{K}^{+}$ & $\mathrm{Na}^{+}$ & $\mathrm{Ca}^{2+}$ & $\mathrm{Mg}^{2+}$ & $\mathrm{Cu}$ & $\mathrm{Fe}$ & $\mathrm{Mn}$ & $\mathrm{Zn}$ \\
\hline & & & & & \multicolumn{3}{|c|}{$\mathrm{mg} \mathrm{dm}^{-3}$} & \multicolumn{2}{|c|}{$\mathrm{cmol}_{\mathrm{c}} \mathrm{dm}^{-3}$} & \multicolumn{4}{|c|}{$\mathrm{mg} \mathrm{dm}{ }^{-3}$} \\
\hline *Soil 1 & 0.51 & 7.46 & 1.77 & 3.64 & 63.3 & 60.0 & 17.0 & 2.09 & 0.58 & 0.19 & 2.03 & 10.43 & 6.21 \\
\hline Soil 2 & 0.42 & 6.60 & 0.10 & 3.65 & 34.2 & 69.2 & 19.0 & 3.10 & 0.80 & 0.29 & 2.86 & 11.40 & 7.35 \\
\hline
\end{tabular}

*Soil 1: Soil of the site in 2015; Soil 2: Soil of the site in 2017.

${ }^{\dagger} \mathrm{N}$ : Nitrogen; pH: Hydrogenionic potential; EC: Electrical conductivity; OM: Organic matter; P: Phosphorus; $\mathrm{K}^{+}$: Potassium;

$\mathrm{Na}^{+}$: Sodium; $\mathrm{Ca}^{2+}$ : Calcium; $\mathrm{Mg}^{2+}$ : Magnesium; $\mathrm{Cu}$ : Copper; Fe: Iron; Mn: Manganese and Zn: Zinc.

Source: Authors.

\subsection{Experimental layout and treatment}

The research was conducted in a randomized blocks design with four repetitions. The treatments were made of combination of four $C$. procera biomass amounts placed into the soil $\left(20,35,50\right.$ and $\left.65 \mathrm{t}^{-1}\right)$ with three planting arrangements of cowpea-radish (2:2, 3:3 and 4:4) in two cultivation seasons, 2015 and 2017.

The intercrops were performed with the cultures alternate-strips, with $50 \%$ of planted area with radish and $50 \%$ with cowpea. Each plot was constituted by radish alternated-rows at the same number of cowpea rows, according to planting arrangement in study, edged by two radish rows bordering one side and two cowpea rows the other side, forming the lateral borders. The total plots areas in the planting arrangements 2:2, 3:3, and 4:4 were 2.40, 3.00, and $3.60 \mathrm{~m}^{2}$, respectively, with useful areas of 1.00, 1.50, and $2.00 \mathrm{~m}^{2}$, with 50; 75 and 100 plants of radish at spacing of $0.25 \mathrm{~m} \times 0.04 \mathrm{~m}$ and $20 ; 30$ and 40 cowpea plants at spacing of $0.25 \mathrm{~m} \times 0.10 \mathrm{~m}$ (Figure 1). 
Figure 1. Cowpea-radish intercrop plots details in a certain $C$. procera dry biomass amount in the planting arrangements 2:2 (A), 3:3 (B) and 4:4 (C) of crops.

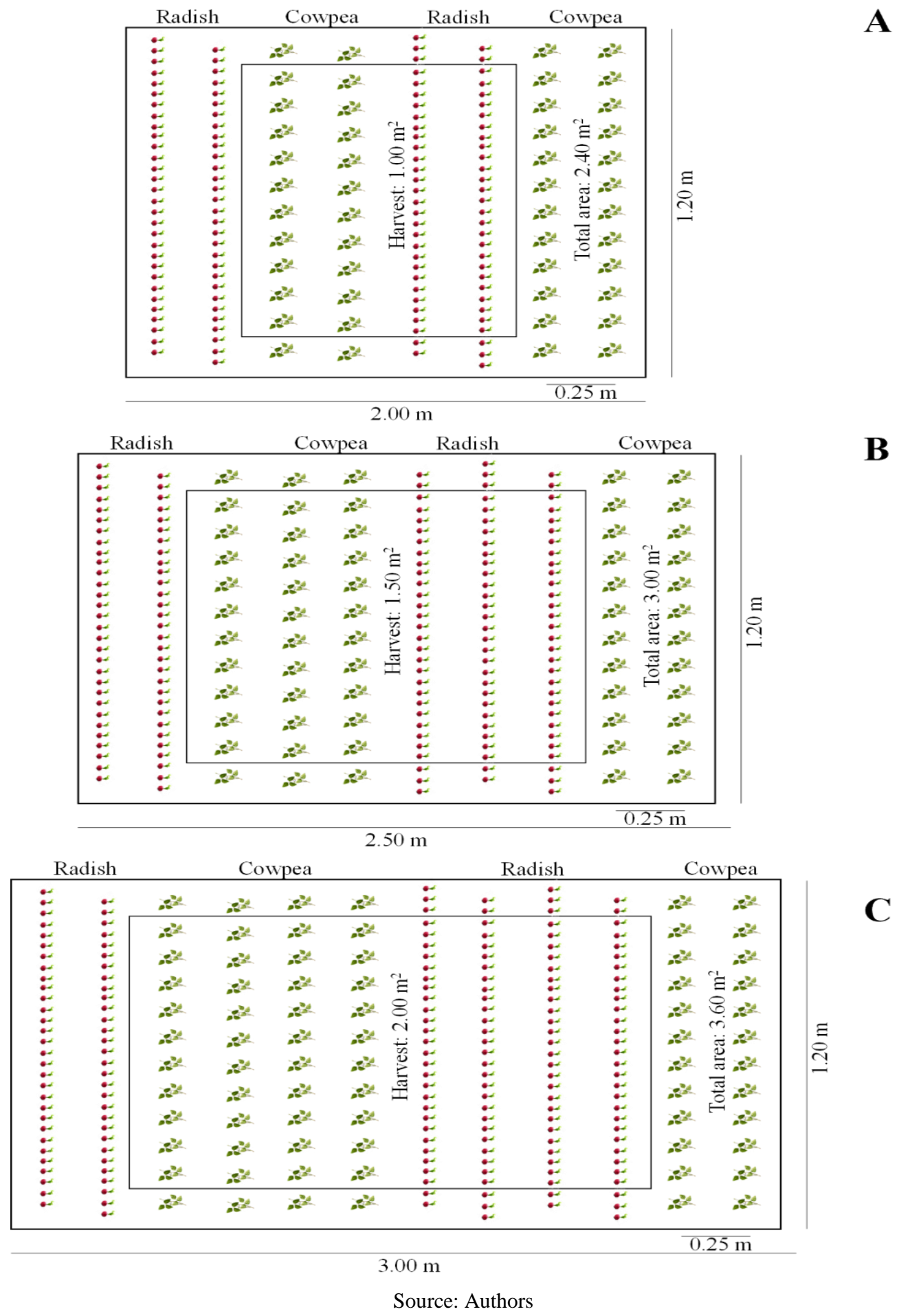

Cowpea and radish single plots were sowed on August 28, 2015 and on August 18, 2017 for the calculation of bioeconomic efficacy indices of intercrops in their optimum population densities proposed by single crops research. The monocrops total plots areas were $1.44 \mathrm{~m}^{2}$ for radish and $3.60 \mathrm{~m}^{2}$ for cowpea, with useful areas of $0.80 \mathrm{~m}^{2}$ and $2.0 \mathrm{~m}^{2}$ (Figure 2). 
Figure 2. Radish (A) and cowpea (B) single crops plot details.

\begin{tabular}{|c|c|c|c|c|c|c|}
\hline o & . & 0. & .- & . & $\mathbf{A}$ & .. \\
\hline . & . & . & - & . & & . \\
\hline - & . & -. & 0. & . & & . \\
\hline . & - & . $\mathrm{N}^{\mathrm{V}}$ & -. & - & $\Xi$ & .. \\
\hline . & - & -. $\triangleright$ & - & a. & J & .. \\
\hline - & - & - $\stackrel{0}{0}$ & - & - & نه & -. \\
\hline . & . & $\cdot{ }_{0}^{\infty}$ & - & - & $\Xi$ & - \\
\hline - & - & - $+\frac{\bar{I}}{\Xi}$ & -. & - & 䒕 & -. \\
\hline . & . & -. & - & - & & -. \\
\hline - & or & . & -. & - & & - \\
\hline - & . & o. & - & - & & - \\
\hline . &. & 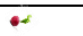 & 0 & . & & -. \\
\hline
\end{tabular}

$\overline{0.20 \mathrm{~m}}$

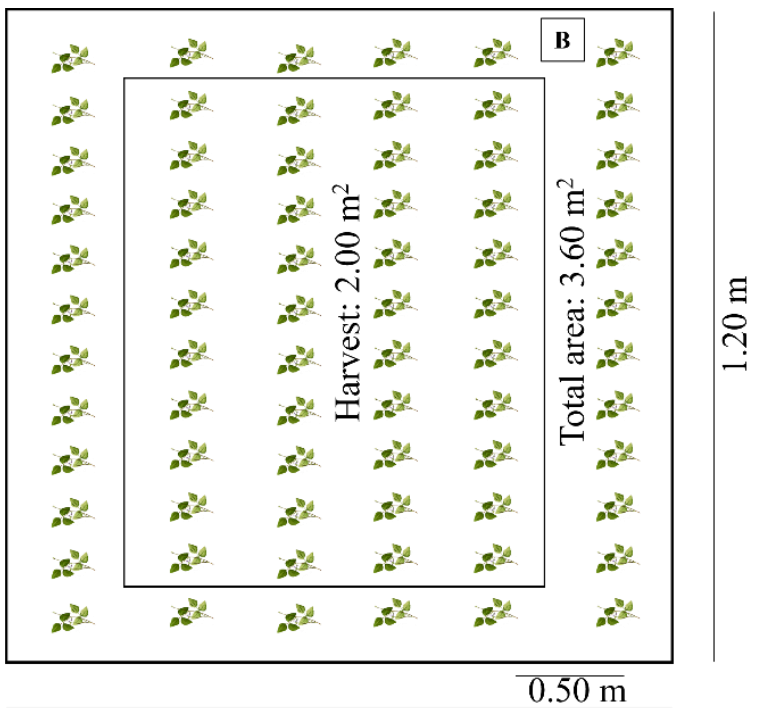

$3.00 \mathrm{~m}$

Source: Authors

Radish crop was planted at $0.20 \mathrm{~m}$ x $0.04 \mathrm{~m}$, with 500,000 $\mathrm{pls} \mathrm{ha}^{-1}$ (Batista et al., 2013), and cowpea at $0.50 \mathrm{~m} \times 0.10$ m, with 200,000 $\mathrm{pls} \mathrm{ha}^{-1}$ (Freire Filho, 2011), not including 30\% of reserved area for corridors and roads. These densities were also used in intercrops tested in this study.

The radish cultivar sowed was Crimson Gigante and of cowpea BRS Itaim, both proposed for planting in the semiarid of Northeastern, Brazil (Dantas Júnior et al. 2014; Vilarinho, 2009).

\subsection{Culture management and practices}

On the cropping sites, were accomplished in the soils plowing, harrowing, and beds lifting. After this, it was accomplished a solarization of 45 days on the beds with the purpose to reduce the soil phytopathogen population.

The green manure $C$. procera for fertilizing of the essays was harvest in sites nearby Mossoró city two months before crops planting of radish and cowpea. In the 2015 experiment, this material was collected on June 29 and in the 2017 experiment on June 19. After this, this material was crushed in small pieces of 2 or 3 centimeters where they put to dry up to get the humidity of $10 \%$. Samples of these materials were sent to the laboratory for macro and micronutrients analyses whose results are in Table 2.

Table 2. Macro and micronutrients contents on the Calotropis procera dry biomass at the cultivation seasons.

\begin{tabular}{cccccccccccc}
\hline \multirow{2}{*}{$\begin{array}{l}\text { Cultivation } \\
\text { season }\end{array}$} & \multicolumn{4}{c}{ Macronutrient $\left(\mathrm{g} \mathrm{kg}^{-1}\right)$} & \multicolumn{3}{c}{ Micronutrient $\left(\mathrm{g} \mathrm{kg}^{-1}\right)$} & \multicolumn{2}{c}{$\begin{array}{c}\mathrm{C} / \mathrm{N} \\
\text { ratio }\end{array}$} \\
\cline { 2 - 11 } & $* \mathrm{~N}$ & $\mathrm{P}$ & $\mathrm{K}$ & $\mathrm{Ca}$ & $\mathrm{Mg}$ & $\mathrm{Fe}$ & $\mathrm{Mn}$ & $\mathrm{Zn}$ & $\mathrm{Cu}$ & $\mathrm{Na}$ & $25: 1$ \\
\hline $\mathrm{S} 1$ & 18.40 & 3.10 & 14.50 & 16.30 & 13.50 & 100.50 & 21.75 & 37.88 & 3.85 & 608.5 \\
\hline $\mathrm{S} 2$ & 15.30 & 0.66 & 25.60 & 8.60 & 4.32 & 94.30 & 16.24 & 29.77 & 3.04 & 207.3 & $25: 1$ \\
\hline
\end{tabular}

$\dagger$ S1: Cultivation season of 2015; S2: Cultivation season of 2017.

* N: Nitrogen; P: Phosphorus; K: Potassium; Ca: Calcium and Mg: Magnesium, Fe: Iron; Mn: Manganese; Zn: Zinc;

$\mathrm{Cu}$ : Copper; Na: Sodium and C/N: Carbon/ Nitrogen ratio.

Source: Authors. 
This fertilizer was placed into the soil at 20 days before crops sowing, on August 8, 2015 and July 28, 2017 at 0-20 $\mathrm{cm}$ depth. Fertilizer incorporation in radish and cowpea monocrops was accomplished in the 18 and $59 \mathrm{t} \mathrm{ha}^{-1}$ amounts, respectively, build on previous researches conducted by Batista et al. (2013) and Vieira (2018).

Daily irrigation was accomplished by micro-sprinkler in two turns to favoring soil microbial activity and mineralization process of the organic matter. The plantings of cowpea and radish crops were made on August 28, 2015 (first season) and August 18, 2017 (second season), in direct sowing at the depth of two centimeters. After the plants emergence of radish and cowpea, at 7 and 10 days, they were thinned, leaving a plant per hole. Hand weeding was made where necessary.

The radish was harvested at 30 days after sowing (DAS) on September 27, 2015 and on September 17, 2017, while cowpea was harvested in four passes through in the interval of 51-65 and 50-62 DAS, in cultivation years.

\subsection{Evaluated indices and indicators}

The bio-economic efficacy of cowpea-radish intercrops was computed by biological indices and economic indicators.

a) LER was computed by the formula (Diniz et al., 2017): $L E R=Y_{\mathrm{rc}} / Y_{\mathrm{r}}+\mathrm{Y}_{\mathrm{cr}} / \mathrm{Y}_{\mathrm{c}}$, where $\mathrm{Y}_{\mathrm{rc}}$ is the marketable roots productivity of radish in intercrop with cowpea; $Y_{\mathrm{r}}$, the productivity of marketable radish roots in monocropping; $\mathrm{Y}_{\mathrm{cr}}$, the cowpea green grain productivity in intercrop with radish; $\mathrm{Y}_{\mathfrak{c}}$, the cowpea green grain productivity in monocropping. If LER > 1 , then a production gain occurs, if LER $=1$ does not have production gain, and if LER $<1$, then production disadvantage occurs.

b) ATER was computed by the formula (Gebru, 2015): $\left[\left(\operatorname{LER}_{r} \times T_{r}\right)+\left(\operatorname{LER}_{c} \times T_{c}\right)\right] / T$. $L_{E R}$ and $L_{r E R}$ are the land equivalent ratios for radish and cowpea. $T_{r}$ is the days number from planting up to radish harvest, $T_{c}$ is the days number from planting up to cowpea harvest, and $\mathrm{T}$ is the total time of the radish-cowpea intercrop. If ATER $>1$, then a production gain occurs, If ATER $=1$ there is no production gain in intercrop, and if ATER $<1$, then there is a production disadvantage in intercrop.

c) AYL was computed by the formula (Cecilio Filho et al., 2015): $\mathrm{AYL}=A \mathrm{AL}_{\mathrm{r}}+\mathrm{AYL}$, in which $\mathrm{AYL}_{\mathrm{r}}=$ $\left[\left\{\left(\mathrm{Y}_{\mathrm{rc}} / \mathrm{Z}_{\mathrm{rc}}\right) /\left(\mathrm{Y}_{\mathrm{r}} / \mathrm{Z}_{\mathrm{r}}\right)\right\}-1\right]$ and $A \mathrm{YL}_{\mathrm{c}}=\left\{\left[\left(\mathrm{Y}_{\mathrm{cr}} / \mathrm{Z}_{\mathrm{cr}}\right) /\left(\mathrm{Y}_{\mathrm{c}} / \mathrm{Z}_{\mathrm{c}}\right)\right]-1\right\}$. AYL is the system actual yield loss, $A \mathrm{YL}_{\mathrm{r}}$ is the radish actual yield loss, $\mathrm{AYL}_{\mathrm{c}}$ is the cowpea actual yield loss, $\mathrm{Y}_{\mathrm{rc}}$ is commercial roots productivity of radish in intercrop with cowpea, $\mathrm{Z}_{\mathrm{rc}}$ is the radish planting proportion in intercrop with cowpea, $\mathrm{Y}_{\mathrm{r}}$ is the productivity of commercial radish roots in monocrop, $\mathrm{Z}_{\mathrm{r}}$ is the radish planting proportion in monocrop, $Y_{\mathrm{cr}}$ is the cowpea green grain productivity in intercrop with radish, $Z_{\mathrm{cr}}$ is the cowpea planting proportion in intercrop with radish, $Y_{c}$ is cowpea green grain productivity in monocropping, and $Z_{c}$ is the cowpea planting proportion in monocrop. If $A Y L>0$, this indicates intercrop accumulated advantage intercrop in regard to monocrop, if $\mathrm{AYL}<0$, this indicates intercrop disadvantage.

d) SPI was estimated by the formula (Pinto et al., 2012): SPI $=\left[\left(Y_{\mathrm{r}} / \mathrm{Y}_{\mathrm{c}}\right) \times \mathrm{Y}_{\mathrm{cr}}\right]+\mathrm{Y}_{\mathrm{rc}}$. $Y_{\mathrm{r}}$ and $\mathrm{Y}_{\mathrm{c}}$ represent the marketable productivity of viable radish roots and cowpea green grains productivity in single crop, respectively. $\mathrm{Y}_{\mathrm{cr}}$ is cowpea green grains productivity in intercrop with radish, and $\mathrm{Y}_{\mathrm{rc}}$ is marketable production of radish roots in intercrop with cowpea. The SPI main advantage is that it expressed in $\mathrm{t} \mathrm{ha}^{-1}$, that is, it standardizes the secondary crop productivity (cowpea) in respect of main crop (radish). This index also identifies the combination that uses growth resources more effectively and also characterizes the performance of productive stability.

e) The production total costs (TC) per hectare were quantified in each treatment. Based upon these values, the indicators $\mathrm{NR}, \mathrm{RR}$, and PM were determined.

f) GR was computed by multiplying the productivities values per hectare by current price paid to the farmer.

g) NR of each treatment was obtained subtracting from GR per hectare, the production TC involved in obtaining the same. 
i) RR was computed as the ratio between GR and TC, that is, RR = GR/TC, corresponding to the quantity of reals obtained by each real invested in radish-cowpea intercrop in response to applied treatments.

j) PM was computed by NR/GR ratio, expressed in percentage.

\subsection{Statistical analysis}

The bio-economic indices were analyzed using univariate analysis of variance for a randomized block design, using the SISVAR program (Ferreira, 2011). After that, a combined analysis was accomplished for each indice or indicator over cultivation years of 2015 and 2017. F of Fisher and Tukey tests were used to compare years of cultivation and planting arrangements. A regression curve was estimated for each indice or indicator with the C. procera amounts, through Table Curve program (Systat Software, 2021). The response functions obtained were evaluated based on the following criteria: biological logic, significance of the mean square of the regression residual (QMRr), high value of the coefficient of determination $\left(\mathrm{R}^{2}\right)$ and significance of the regression parameters, using the $t$ test to $5 \%$ probability level.

\section{Results and Discussion}

It was not observed interaction between $C$. procera amounts and planting arrangements for no biological index assessed (Table 3). However, an interaction was registered between these $C$. procera amounts and cultivation seasons for SPI (Table 3).

Table 3. Land equivalent ratio (LER), area time equivalency ratio (ATER), actual yield loss (AYL) and system productivity index (SPI) of the cowpea-radish intercropping in response to Calotropis procera biomass amounts placed into the soil, planting arrangements and cultivation seasons.

\begin{tabular}{|c|c|c|c|c|c|c|c|c|}
\hline \multirow{2}{*}{$\begin{array}{l}\text { Amount of } \\
\text { C. procera } \\
\text { biomass } \\
\left(\mathrm{t} \mathrm{ha}^{-1}\right)\end{array}$} & \multicolumn{2}{|c|}{ LER } & \multicolumn{2}{|c|}{ ATER } & \multicolumn{2}{|c|}{ AYL } & \multicolumn{2}{|c|}{ SPI (t ha $\left.{ }^{-1}\right)$} \\
\hline & & & & & & & $\begin{array}{c}1^{\text {st }} \text { Season } \\
\text { S1 }\end{array}$ & $\begin{array}{c}2^{\text {nd }} \text { Season } \\
\text { S2 }\end{array}$ \\
\hline 20 & & & & & & & $6.24 b$ & $13.82 \mathrm{a}$ \\
\hline 35 & & & & & & & $6.95 b$ & $15.58 \mathrm{a}$ \\
\hline 50 & & & & & & & $7.20 \mathrm{~b}$ & $18.01 \mathrm{a}$ \\
\hline 65 & & & & & & & $7.54 \mathrm{~b}$ & $18.72 \mathrm{a}$ \\
\hline \multirow[b]{2}{*}{$\begin{array}{c}\text { Planting } \\
\text { arrangement }\end{array}$} & \multicolumn{2}{|c|}{ LER } & \multicolumn{2}{|c|}{ ATER } & \multicolumn{2}{|c|}{ AYL } & \multicolumn{2}{|c|}{ SPI $\left(\mathrm{t} \mathrm{ha}^{-1}\right)$} \\
\hline & $\begin{array}{c}1^{\text {st }} \text { Season } \\
\text { S1 }\end{array}$ & $\begin{array}{c}2^{\text {nd }} \text { Season } \\
\text { S2 }\end{array}$ & $\begin{array}{c}1^{\text {st }} \text { Season } \\
\text { S1 }\end{array}$ & $\begin{array}{c}2^{\text {nd }} \text { Season } \\
\text { S2 }\end{array}$ & $\begin{array}{c}1^{\text {st }} \text { Season } \\
\text { S1 }\end{array}$ & $\begin{array}{c}2^{\text {nd }} \text { Season } \\
\text { S2 }\end{array}$ & $\begin{array}{c}1^{\text {st }} \text { Season } \\
\text { S1 }\end{array}$ & $\begin{array}{c}2^{\text {nd }} \text { Season } \\
\text { S2 }\end{array}$ \\
\hline $2: 2$ & $1.41 \mathrm{aB}$ & $1.51 \mathrm{aA}$ & $0.96 \mathrm{bA}$ & $1.16 \mathrm{aA}$ & $0.80 \mathrm{aB}$ & $1.02 \mathrm{aA}$ & $6.99 \mathrm{bA}$ & $17.74 \mathrm{aA}^{*}$ \\
\hline $3: 3$ & $1.62 \mathrm{aA}$ & $1.40 \mathrm{bA}$ & $1.05 \mathrm{aA}$ & $1.01 \mathrm{aB}$ & $1.15 \mathrm{aA}$ & $0.80 \mathrm{bA}$ & $7.06 \mathrm{bA}$ & $16.00 \mathrm{aB}$ \\
\hline $4: 4$ & $1.62 \mathrm{aA}$ & $1.40 \mathrm{bA}$ & $1.03 \mathrm{aA}$ & $1.00 \mathrm{aB}$ & $1.16 \mathrm{aA}$ & $0.80 \mathrm{bA}$ & $6.90 \mathrm{bA}$ & $15.88 \mathrm{aB}$ \\
\hline
\end{tabular}
$*$ Means followed by the same lowercase letter in the row or uppercase letter in the column do not differ by $\mathrm{F}$ test or Tukey, respectively,
at $5 \%$ probability.

Source: Authors

SPI of the cultivation second season (S2) and of intercropped system (S) increased with C. procera amounts placed into the soil until the highest values of 18.80 and $13.15 \mathrm{t} \mathrm{ha}^{-1}$ in the amounts of 62.09 and $62.51 \mathrm{t}$ ha ${ }^{-1}$ of green fertilizer, decreasing until the application of the last amount (Figure 3D). This index in the first cultivation season (S1) only had an increase of 1.29 between the smaller and greater amount of applied green manure. Increase in this index in S1 and S2 suggests that the green fertilizer is an important factor in economic feasibility of the intercrops (Pinto et al., 2012). Conversely, the SPI mean values in S2 within C. procera amounts and within planting arrangements differed significantly from those of S1. These results are partly by cause of radish productivity in single crop in S2 that reached higher values (Table 3). 
Figure 3. Land equivalent ratio, LER (A), area time equivalency ratio, ATER (B), and actual yield loss, AYL (C), in response to Calotropis procera biomass amounts and the system productivity index, SPI (D) of radish-cowpea intercrop in response to Calotropis procera biomass amounts placed into the soil and cultivation seasons (S1 and S2).

A

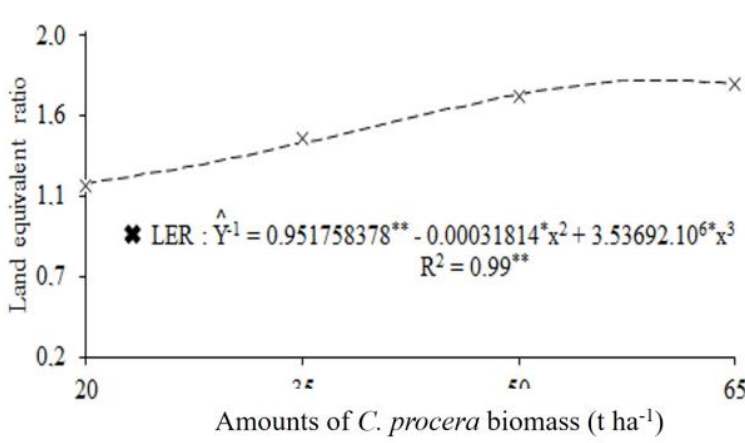

C

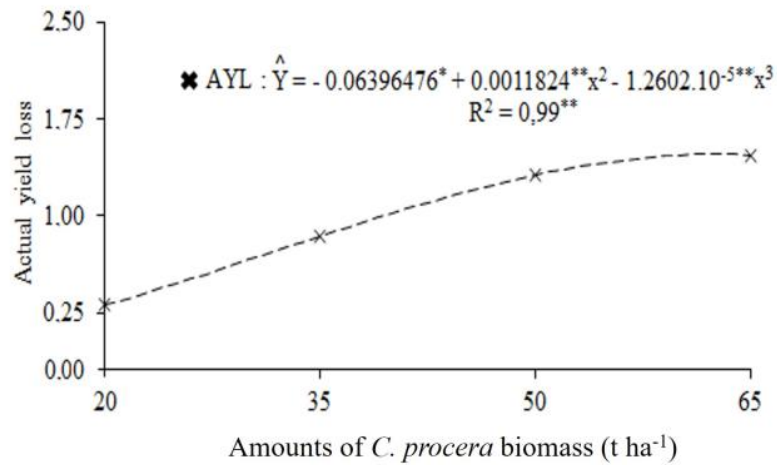

B
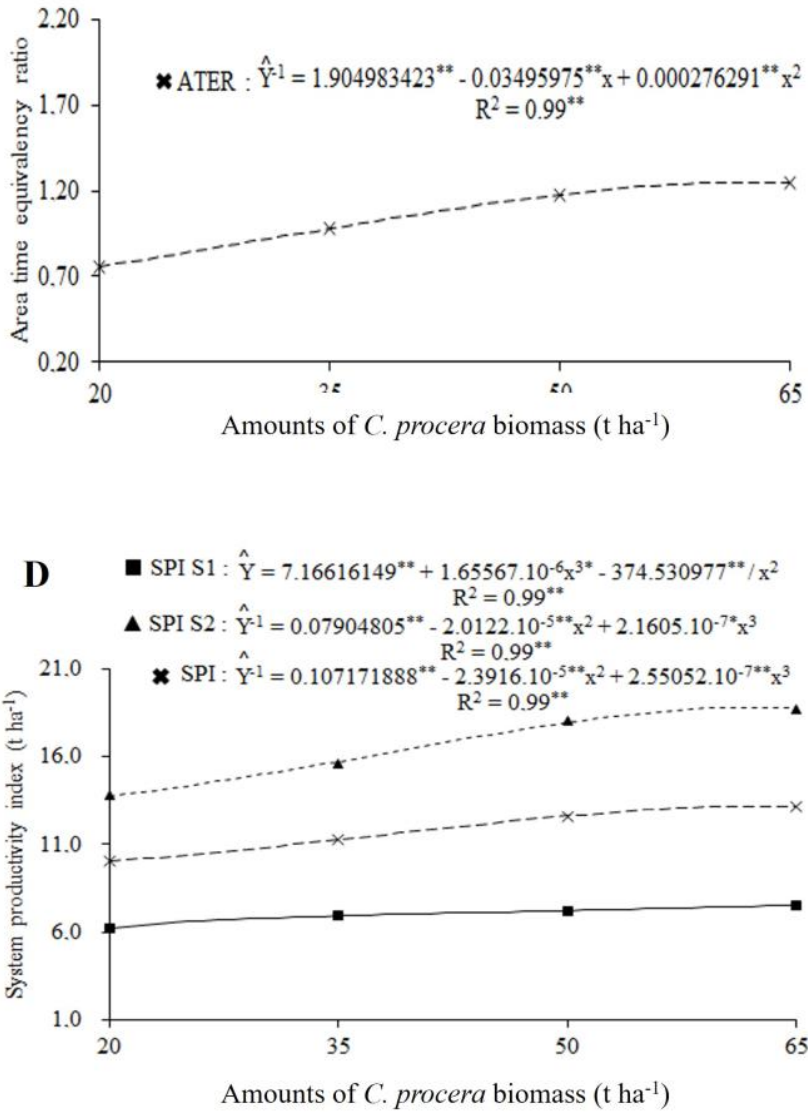

Source: Authors.

It was also not observed interaction between $C$. procera biomass amounts and cultivation seasons for LER, ATER, and AYL (Table 3). Although, LER, ATER and AYL increased with C. procera crescent amounts placed into the soil, until the highest values of $1.75,1.25$ and 1.48 in green fertilizer amounts of 59.97; 63.27 and $62.55 \mathrm{t} \mathrm{ha}^{-1}$, then decreasing until the last amount (Figures 3A, 3B and 3C).

Based upon in LER and ATER, it can infer that the monocropping would need $75 \%$ more area and $25 \%$ more areatime to produce the equivalent in the intercrop fertilized with C. procera in one hectare (Diniz et al., 2017; Gebru, 2015). Both indices can assess the biological benefits of an intercrop (Rana \& Rana, 2011), and thus express whether the intercrop become economically viable and profitable to be implemented by farmers (Maduwanthi \& Karunarathna, 2019).

The positive value for AYL indicates intercropping advantage and determines complementarity between cultures, thus expressing the grade of intra and interspecific competition by the ambient recources at the different cultivation seasons (Cecilio Filho et al., 2015).

Significant interactions were also recorded between cultivation seasons and planting arrangements for the indices LER, ATER, AYL and SPI (Table 3).

Studying the cultivation seasons within each arrangement was observed there were significant differences between SPI values. The values for S1 stood out from those of S2 in all planting arrangements (Table 3). Mean values for LER, ATER and AYL in S2 differed from those of S1 in the planting arrangement 2:2. Within 3: 3 and 4: 4 arrangements, LER and AYL 
means in S1 stood out from those of S2, while the ATER mean values showed opposite comportment of the LER and AYL within these planting arrangements.

Within S1, LER and AYL mean values in the 3: 3 and 4: 4 planting arrangements stood out from those in the 2: 2 planting arrangement. Within S2, mean values of LER and AYL were similar for planting arrangements. Within S1, ATER and SPI mean values had the same behavior as LER and AYL in S2. Conversely, within that same growing season, ATER and SPI average values in the 2: 2 planting arrangement stood out from those of 3: 3 and 4: 4 planting arrangements.

Significant interactions between cultivation seasons and $C$. procera biomass amounts in the GR, NR, RR and PM were observed (Table 4).

Table 4. Mean values for gross revenue (GR), net revenue (NR), rate of return (RR) and profit margin (PM) of cowpea-radish intercrop (A and $\mathrm{B}$ ) in response to Calotropis procera biomass amounts placed into the soil, planting arrangements and cultivation seasons.

\begin{tabular}{|c|c|c|c|c|c|c|c|c|}
\hline \multicolumn{9}{|c|}{ A. Cultivation season within each Calotropis procera amount } \\
\hline $\begin{array}{l}\text { Amount of } \\
\text { C. procera }\end{array}$ & \multicolumn{2}{|c|}{$\begin{array}{c}\mathrm{GR} \\
\left(\mathrm{R} \$ \mathrm{ha}^{-1}\right)\end{array}$} & \multicolumn{2}{|c|}{$\begin{array}{c}\mathrm{NR} \\
\left(\mathrm{R} \$ \mathrm{ha}^{-1}\right)\end{array}$} & \multicolumn{2}{|c|}{ RR } & \multicolumn{2}{|c|}{$\begin{array}{l}\mathrm{PM} \\
(\%)\end{array}$} \\
\hline biomass & $1^{\text {st }}$ Season & $2^{\text {nd }}$ Season & $1^{\text {st }}$ Season & $2^{\text {nd }}$ Season & $1^{\text {st }}$ Season & $2^{\text {nd }}$ Season & $1^{\text {st }}$ Season & $2^{\text {nd }}$ Season \\
\hline$\left(\mathrm{t} \mathrm{ha}^{-1}\right)$ & S1 & S2 & S1 & S2 & S1 & S2 & $\mathrm{S} 1$ & $\mathrm{~S} 2$ \\
\hline 20 & $24,360.49 \mathrm{~b}$ & $31,750.48 \mathrm{a}$ & $9,055.64 \mathrm{~b}$ & $16,346.89 \mathrm{a}$ & $1.59 \mathrm{~b}$ & $1.88 \mathrm{a}$ & $36.86 \mathrm{~b}$ & $41.48 \mathrm{a} *$ \\
\hline 35 & $33,835.89 \mathrm{a}$ & $35,565.38 \mathrm{a}$ & $14,746.67 \mathrm{a}$ & $16,662.36 \mathrm{a}$ & $1.77 \mathrm{a}$ & $2.06 \mathrm{a}$ & $42.78 \mathrm{a}$ & $47.03 \mathrm{a}$ \\
\hline 50 & $37,848.77 \mathrm{a}$ & $39,715.54 \mathrm{a}$ & $15,388.77 \mathrm{a}$ & $17,376.94 \mathrm{a}$ & $1.68 \mathrm{a}$ & $1.78 \mathrm{a}$ & $40.09 \mathrm{a}$ & $41.75 \mathrm{a}$ \\
\hline 65 & $41,592.96 \mathrm{a}$ & $37,711.34 \mathrm{a}$ & $16,012.34 \mathrm{a}$ & $16,416.13 \mathrm{a}$ & $1.62 \mathrm{a}$ & $1.49 \mathrm{a}$ & $36.63 \mathrm{a}$ & $30.94 \mathrm{a}$ \\
\hline \multicolumn{9}{|c|}{ B. Mean values for planting arrangements } \\
\hline $\begin{array}{c}\text { Planting } \\
\text { arrangement }\end{array}$ & \multicolumn{2}{|c|}{$\begin{array}{c}\text { GR } \\
\left(\mathrm{R} \$ \mathrm{ha}^{-1}\right)\end{array}$} & \multicolumn{2}{|c|}{$\begin{array}{c}\mathrm{NR} \\
\left(\mathrm{R} \$ \mathrm{ha}^{-1}\right)\end{array}$} & \multicolumn{2}{|c|}{ RR } & \multicolumn{2}{|c|}{$\begin{array}{l}\text { PM } \\
(\%)\end{array}$} \\
\hline $2: 2$ & \multicolumn{2}{|c|}{$34,208.15 \mathrm{~A}$} & \multicolumn{2}{|c|}{$13,578.54 \mathrm{~A}$} & \multicolumn{2}{|c|}{$1.68 \mathrm{~A}$} & \multicolumn{2}{|c|}{$38.77 \mathrm{~A}$} \\
\hline $3: 3$ & \multicolumn{2}{|c|}{$35,932.28 \mathrm{~A}$} & \multicolumn{2}{|c|}{$15,364.88 \mathrm{~A}$} & \multicolumn{2}{|c|}{$1.77 \mathrm{~A}$} & \multicolumn{2}{|c|}{$42.39 \mathrm{~A}$} \\
\hline $4: 4$ & \multicolumn{2}{|c|}{$35,752.39 \mathrm{~A}$} & \multicolumn{2}{|c|}{$15,308.73 \mathrm{~A}$} & \multicolumn{2}{|c|}{$1.76 \mathrm{~A}$} & \multicolumn{2}{|c|}{$41.26 \mathrm{~A}$} \\
\hline
\end{tabular}

*Means followed by the same lowercase letter in the row or by the same uppercase letter in the column do not differ by $\mathrm{F}$ test or Tukey at $5 \%$ probability.

Source: Authors

Studying $C$. procera biomass amounts comportment within each cultivation season, it was registered an increment in the GR and NR in S2 and in the intercrop with the $C$. procera crescent amounts placed into the soil until the highest values of $39,442.54 ; 17,663.57 ; 38,782.16$ and $16,382.85 \mathrm{RS} \mathrm{ha}^{-1}$ in the biomass amounts of $54.05 ; 61.28 ; 60.66$ and $53.00 \mathrm{t}$ ha ${ }^{-1} \mathrm{of}$ the green fertilizer, then decreasing until the last amount of the applied green manure (Figure 4A). Conversely, gross and net revenues in $\mathrm{S} 1$ only increased by about $17,106.61$ and $6,968.72 \mathrm{R} \$ \mathrm{ha}^{-1}$ between the lowest and highest amount of the fertilizer placed into the soil. 
Figure 4. Gross revenue, GR and net revenue, NR (A), rate of return, RR and profit margin, PM (B) of the cowpea-radish intercrop in response to the Calotropis procera biomass amounts and cultivation seasons (S1 and S2).
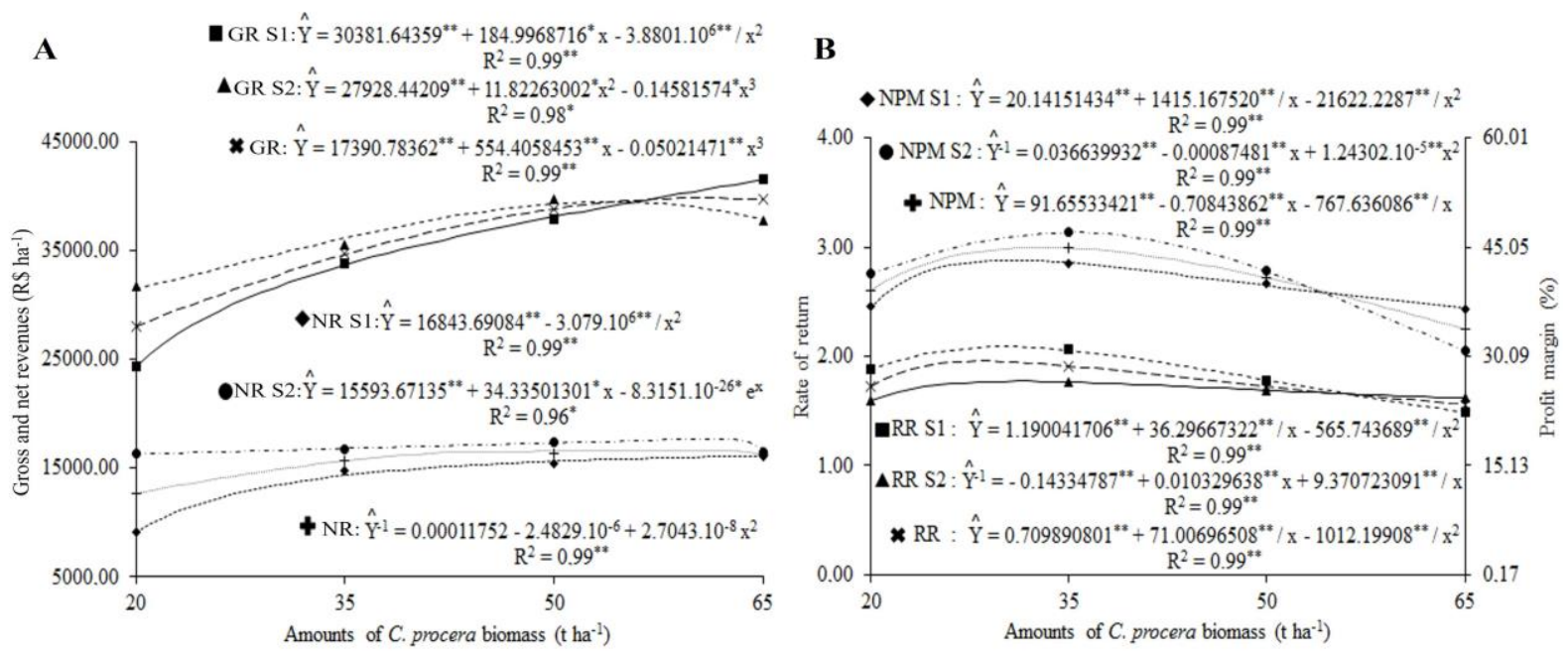

Source: Authors.

$\mathrm{RR}$ and PM in S1 and S2 and in intercrop (S) increased with the increasing of C. procera biomass amounts placed into the soil until the highest values of 1.77 and $43.29 \% ; 2.09$ and $47.06 \%$, and 1.96 and $45.01 \%$ in the biomass amounts of 31.17 and $30.56 ; 30.11$ and 35.19; and 28.51 and $32.92 \mathrm{t} \mathrm{ha}^{-1}$ of the green fertilizer, then decreasing until the last added amount (Figure 4B).

The increase in these economic indicators is attributed to crop yields that allowed a more efficient usage of ambient recources, as previously registered in biological efficiency indices (Figures 4A and 4B). Thus, besides guarantee food diversification, the reduction of risks in the event of a drop in productivity of a culture can be reduced with usage of intercropping (Kiwia et al., 2019). Nunes et al. (2018) claim that, the complementary of the involved cultures in the intercrop; can avoid problems in usage of ambient recources.

Studying the cultivation seasons within each $C$. procera biomass amount, they were observed that the mean values for GR, NR, RR, and PM in S2 stood out from those of S1 in the biomass amount of $20 \mathrm{t} \mathrm{ha}^{-1}$ of the green fertilizer. In the amounts of 35,50 and $65 \mathrm{t} \mathrm{ha}^{-1}$, there were no significant differences between mean values of economic indicators in the cultivation seasons (Table 4).

There were no significant differences between mean values for economic indicators in the planting arrangements of the cultures (Table 4).

Finally, values obtained in the biological indices agree with those reached in economic indicators. Thus, economic indicators values show that the intercrop as agricultural system is increasingly recognized as a farming practice for sustainable economic development in the family farming (Jensen et al., 2015; Bedoussac et al., 2015).

\section{Conclusions}

The cowpea-radish intercrop is highly viable, as it presents bio-economic and sustainable efficacy when properly fertilized with $C$. procera biomass and well managed in respect to its planting arrangement. The greatest biological efficiencies of the cowpea-radish association were attained with LER and ATER of 1.75 and 1.25; AYL and SPI of 1.48 and $13.15 \mathrm{t}$ ha ${ }^{-1}$, respectively, in the amount of $62 \mathrm{t} \mathrm{ha}^{-1}$ of $C$. procera biomass in the planting arrangements 2: 2 and 3: 3 . The largest net economic return (NR) of 16,382.85 $\mathrm{R} \$ \mathrm{ha}^{-1}$ was attained in the amount of $52 \mathrm{t} \mathrm{ha}^{-1}$ of $C$. procera in the planting arrangement 3: 3. LER, ATER, AYL, SPI, GR, NR, RR, and PM indices assessed can help the farmer to make adequate decisions in the 
implantation of his intercropped production system concerning sustainability. For future research with intercrops of cowpea and tuberous vegetables, urges the urgent need to study the interactions between the following production factors: green manuring, cultures planting arrangement and plant population density besides the appropriate times to plant the cultures in intercrop.

\section{Acknowledgments}

Special thanks are due to the National Council for Scientific and Technological Development (CNPq/Brazil) process $n^{\circ}$ 303555/2012-2 and Coordination for the Improvement of Higher Education Personnel (CAPES/Brazil) - Finance Code 001, for financial support and to the research group at the Department of Agronomic and Forest Sciences of the Federal Rural University for the Semi-Arid, which develops technologies for growing crops on family farms.

\section{References}

Alvares, C. A., Stape, J. L., Sentelhas, P. C., Gonçalves, J. L. de M., \& Sparovek, G. (2014). Koppen's climate classification map for Brazil. Meteorologische Zeitschrift, 22 (6), 711-728. 10.1127/0941-2948/2013/0507

Batista, M. A. V., Bezerra Neto, F., Ambrosio, M. M. Q., Guimarães, L. M. S., Saraiva, J. P. B., \& Silva, M. L. (2013). Atributos microbiológicos do solo e produtividade de rabanete influenciados pelo uso de espécies espontâneas. Horticultura Brasileira, 31 (4), 587-594. 10.1590/S0102-05362013000400013

Bedoussac, L., Journet, E. P., Hauggaard-Nielsen, H., Naudin, C., Corre-Hellou, G., Jensen, E. S., Prieur, L., \& Justes, E. (2015). Ecological principles underlying the increase of productivity achieved by cereal-grain legume intercrops in organic farming. A review. Agronomy for Sustainable Development, 35(3), 911-935. 10.1007/s13593-014-0277-7

Bhatt, B. K. (2011). Statistical evaluation for analysing intercropping experiments. LAP LAMBERT Academic Publishing. 93p.

Cecílio Filho, A. B., Bezerra Neto, F., Rezende, B. L. A., Barros Júnior, A. P., \& Lima, J. S. S. (2015). Indices of bio-agroeconomic efficiency in intercropping systems of cucumber and lettuce in greenhouse. Australian Journal of Crop Science, 9(12), 1154-1164.

Chaves, A. P., Bezerra Neto, F., Lima, J. S. S., Silva, J. N., Nunes, R. L. C., Barros Júnior, A. P., Lima, G. K. L., \& Santos, E. C. (2020). Cowpea and beet intercropping agro-economic dynamics under spatial arrangement and cowpea population density. Horticultura Brasileira, 38 (2), 192-203. 10.1590/s0102053620200212

Dantas Júnior, G. J., Silva, P. F., Matos, R. M., Borges, V. E., \& Dantas Neto, J. (2014). Produção comercial de rabanete fertirrigado com nitrogênio em ambiente protegido. Revista Educação Agrícola Superior, 29 (2), 99-104. 10.12722/0101-756X.v29n02a10

Diniz, W. J. S., Silva, T. G. F., Ferreira, J. M. S., Santos, D. C., Moura, M. S. B., Araújo, G. G. L., \& Zolnier, S. (2017). Forage cactus-sorghum intercropping at different irrigation water depths in the Brazilian semiarid region. Pesquisa Agropecuária Brasileira, 52(9), 724-733. 10.1590/S0100-204X2017 000900004

Favacho, F. S., Lima, J. S. S., Bezerra Neto, F., Silva, J. N., \& Barros Júnior, A. P. (2017). Productive and economic efficiency of carrot intercropped with cowpea vegetable resulting from green manure and different spatial arrangements. Revista Ciência Agronômica, 48 (2), $337-346$.

Ferreira, D. F. (2011). Sisvar: a computer statistical analysis system. Ciência e Agrotecnologia, 35 (6), 1039-1042. 10.1590/S1413-70542011000600001

Freire Filho, F. R. (2011). Feijão-caupi no Brasil: Produção, melhoramento genético, avanços e desafios. Embrapa Meio-Norte. 84 p.

Gebru, H. (2015). A review on the comparative advantages of intercropping to mono-cropping system. Journal of Biology, Agriculture and Healthcare, 5(9), $1-13$.

Jensen, E. S., Laurent Bedoussac, L., Carlsson1, G., Journet, E. P., Justes, E., \& Hauggaard-Nielsen, H. (2015). Enhancing yields in organic crop production by eco-functional intensification. Sustainable Agriculture Research, 4 (3), 42-50. 10.5539/sar.v4n3p42

Kiwia, A., Kimani, D., Harawa, R., Jama, B., \& Sileshi, G. W. (2019). Sustainable intensification with cereal-legume intercropping in Eastern and Southern Africa. Sustainability, 11 (10), 1-18. 10.3390/su11102891

Maduwanthi, A. K. M. R. B., \& Karunarathna, B. (2019). Biological and economic benefit of okra (Abelmoschus esculentus L.) cowpea (Vigna unguiculata L. Walp) intercropping in sandy Regosol. Middle East Journal of Agriculture Research, 8 (1), 28-34.

Moraes, E. C., Lima, J. S. S., Bezerra Neto, F., Linhares, P. C. A.; Costa, A. P., Crispim, J. F.; Andrade, L. I. F.; \& Rodrigues, G. S. O. (2019). Effects of different roostertree (Calotropis procera) amounts and spatial arrangements on the performance of the beet-cowpea intercropping system. Australian Journal of Crop Science, 13 (4), 486-493. 10.21475/ajcs.19.13.04.p843.

Nunes, R. L. C., Bezerra Neto, F., Lima, J. S. S., Barros Júnior, A. P., Chaves, A. P., \& Silva, J. N. (2018). Agro-economic responsiveness of radish associations with cowpea in the presence of different amounts of Calotropis procera, spatial arrangements and agricultural crops. Ciência e Agrotecnologia, 42(4):350-364. 10.1590/1413-70542018424010318 
Pereira, M. F. S., Bezerra Neto, F., Barros Júnior, A. P., Linhares, P. C. F., Silva, M. L., \& Lins, H. A. (2018). Agro-economic feasibility of intercropped systems of radish and cowpea-vegetable manured with roostertree biomass. Journal of Agricultural Science, 10 (10), 206-212. 10.5539/jas.v10n10p206

Pereira, M. F. S., Bezerra Neto, F., Pontes, F. S. T., Linhares, P. C. F., Silva, M. L., \& Silva, I. N. (2016). Productive performance of cowpea-radish intercropping under different amounts of rooster tree biomass incorporated into the soil. Revista Brasileira de Engenharia Agrícola e Ambiental, 20(11), 965971. 10.1590/1807-1929/agriambi.v20n11p965-971

Pinto, C. M., Pinto, O. R. O., \& Pitombeira, J. B. (2012). Mamona e girassol no sistema de consorciação em arranjo de fileiras: habilidade competitiva. Revista Brasileira de Agropecuária Sustentável, 2(2), 103-113. 10.21206/rbas.v2i2.172

Rana, S. S., \& Rana, M. C. (2011). Cropping system. College of Agriculture, CSK Himachal Pradesh Krishi Vishvavidyalaya. 80 10.13140/RG. 2.2.22041.42083

Ribeiro, G. M., Bezerra Neto, F., Lima, J. S.S., Silva, M. L., Barros Júnior, A. P., \& Santos, E. C. (2018). Productive performance of carrot and cowpea intercropping system under different spatial arrangements and population densities. Revista Caatinga, 31 (1), 19-27

Santos, H. G., Jacomine, P. K. T., Anjos, L. H. C., Oliveira, V. A., Lumbreras, J. F., Coelho, M. R., \& Cunha, T. J. F. (2018). Sistema brasileiro de classificação de solos. Embrapa. 356 p.

Schons, A., Streck, N. A., Storck, L., Buriol, G. A., Zanon, A. J., Pinheiro, D. G., \& Kraulich, B. (2009). Arranjos de plantas de mandioca e milho em cultivo solteiro e consorciado: crescimento, desenvolvimento e produtividade. Revista Bragantia, 68 (1), 155-167.

Silva, R. C. P., Bezerra Neto, F., Silva, M. L., Barros Júnior, A. P., Almeida, A. E. S., \& Vieira, F. A. (2018). Effect of rooster tree green manure on carrot and lettuce intercropping system. Revista Caatinga, 31 (3), 551-559.

Systat Software Inc. 2021. Table curve 3D Academic Edition. Systat Software Inc.

Valadares, R. V., Ávila-Silva, L., Teixeira, R. S., Sousa, R. N., \& Vergütz, L. (2016). Green manures and crop residues as source of nutrients in tropical environment. In: Larramendy, M. L., \& Soloneski, S. Organic fertilizers: From basic concepts to applied outcomes. IntechOpen. Cap.3, p.51-84. doi $10.5772 / 62981$

Vieira, F. A., Bezerra Neto, F., Silva, M. L., Lima, J. S. S., Barros Júnior, A. P., \& Silva, I. N. (2018). Technical-economic efficiency of the yield of green grains of cowpea fertilized with roostertree. Revista Caatinga, 31 (2), 504-510. 10.1590/1983-21252018v31n227rc

Vilarinho, A. A. (2009). Artigo: Feijão-caupi com grãos para exportação. Pelotas: Grupo Cultivar de Publicações Ltda. 2p. https://www. grupocultivar.com.br/noticias/artigo-feijao-caupi-com-graos-para-exportacao 